\title{
Interferon Beta Measurement
}

National Cancer Institute

\section{Source}

National Cancer Institute. Interferon Beta Measurement. NCI Thesaurus. Code C81995.

The determination of the amount of interferon beta present in a sample. 